\title{
Isomorphic modification of calcium hydroxyapatite by strontium
}

\author{
V.L.Karbivskyy, N.A.Kurgan \\ G.Kurdyumov Institute for Metal Physics, National Academy of Sciences \\ of Ukraine, 36 Vernadsky Blvd., 03680 Kyiv, Ukraine
}

\section{Received September 09, 2015}

\begin{abstract}
X-ray photoelectron spectroscopy studies changes in the electronic structure of calcium hydroxyapatite with partial or total isomorphous substitution of $\mathrm{Ca}$ for $\mathrm{Sr}$ is reported in the current work. It is established significant increase in the binding energy of the core levels for calcium, oxygen and phosphorus atoms, indicating electronic density loss from these atoms and increase of the covalent component in general balance of the chemical bond. Based on numerical calculations by the LMTO method it was concluded that indirect metal-metal interaction for strontium apatite in triangles of the metal atoms is less expressed.
\end{abstract}

Keywords: X-ray photoelectron spectroscopy, quantum-mechanical modeling, hydroxyapatite, electronic structure, isomorphic modification.

Методом рентгеновской фотоэлектронной спектроскопии проведено исследование изменений электронной структуры гидроксоапатита кальция при частичном или полном изоморфном замещениии Сa на Sr. Установлено значительное увеличение энергии связи остовных уровней атомов кальция, кислорода и фосфора, свидетельствующее об уходе с них электронной плотности и увеличении доли ковалентной составляющей в общем балансе химсвязи. На основании расчетных данных, полученных методом ЛМТО, сделан вывод о менее выраженном косвенном взаимодействии металл-металл для апатита стронция в треугольниках из атомов металла.

Ізоморфна модифікація гідроксоапатиту кальцію стронцієм. В.Л.Карбівський, Н.А.Курган.

Методом рентгенівської фотоелектронної спектроскопії проведено дослідження змін електронної структури гідроксоапатиту кальцію при частковому або повному ізоморфному заміщенні Са на Sr. Виявлено помітні зміни в енергії зв'язку остовних рівнів атомів кальцію, кисню та фосфору, що свідчать про відхід з них електронної щільності та збільшенні долі ковалентної складової у загальному балансі хімзв'язку. На підставі розрахункових даних, отриманих методом ЛМТО, зроблено висновок про менш виражену непряму взаємодію метал-метал для апатиту стронцію у трикутниках з атомів металу.

\section{Introduction}

Recently besides other applications nanodisperse calcium hydroxyapatite (HAP, $\left.\mathrm{Ca}_{10}\left(\mathrm{PO}_{4}\right)_{6}(\mathrm{OH})_{2}\right)$ is considered as a matrix for a burial radioactive wastes and environmentally dangerous compounds of heavy metals. Large specific surface area of several hundred square meters per one gram of substance determines high reactivity of the nanodisperse calcium hydroxyapatite [1-9].

Available technologies of treatment and storage of toxic waste are mainly based on the mechanism of chemical binding of the toxic substances, which in practice have the problems such as use of hazardous chemicals, and subsequent utilization of chemically unstable mixes [10-12]. The use of 
calcium hydroxyapatite for long-term storage of radioactive waste and toxic substances will significantly simplify the technology of safe waste management [13-17].

A key task in the development of sorbents based on apatite is to find out the stability of apatite structure after immobilization of heavy metals (in particular $\mathrm{Sr}$, $\mathrm{U}, \mathrm{Pb}, \mathrm{Ba}$ ), so the goal of this study was to clarify the changes of calcium apatite electronic structure, initiated by substitution of calcium atoms for strontium atoms. Research was conducted using X-ray photoelectron spectroscopy, as the most direct research method of electronic structure of chemical compounds with application of LMTO quantum mechanical modeling.

\section{Materials and methods}

Samples of calcium hydroxyapatite with different stoichiometry and varying degree of substitution of strontium were obtained by "wet" method using aqueous solutions of calcium hydroxide concentration from 0.5 to $0.12 \%$, and diluted solution of phosphoric acid at a concentration from 0.1 to $5 \%$, while keeping the ratio of $\mathrm{Ca} / \mathrm{P}$ in the range from 1.5 to 1.9 . Thus, the reaction mass was thoroughly mixed and heated since the beginning of mixing at $30-100^{\circ} \mathrm{C}$ for $21965 \mathrm{~h}$. Strontium nitrate $\mathrm{Sr}\left(\mathrm{NO}_{3}\right)_{2}$ with qualification "analytical grade" was used as a source of strontium.

$\mathrm{X}$-ray photoelectron spectra were obtained by "JEOL" photoelectron spectrometer "JSPM-4610", using a non-monochromatic Mg Ko (1253.6 eV) X-ray source. Vacuum in the analytical chamber during the experiment was $10^{-7} \mathrm{~Pa}$, the determination accuracy of electron binding energy is $0.1 \mathrm{eV}$. Taking into account the charge, accumulating on insulating sample during the experiment, to calibrate X-ray photoelectron spectra the sample surface was coated by the thin layer of gold on. Calibration of the X-ray photoelectron spectra was carried by Au $4 f$ lines binding energy of gold, which allowed to obtain a sufficiently high accuracy of electron binding energies for the samples element. $K_{\alpha}$-spectra of oxygen were obtained on spectrometer-monochromator XSM-500.

Quantum-mechanical calculations of apatites electronic structure were made with the linear method of MT-orbitals (LMTO) using data about the position of atom in the unit cell. Self-consistent calculations of the electronic structure of the crystals (total and partial densities of states (DOS)) were made using the LMTO method, taking into account combined amendments. Core electrons charge density was included in the self-consistent procedure. For exchange-correlation part of the potential, the BarthHedin approximation was used. The calculations were held in scalar-relativistic approximation, in other words all relativistic effects (mass on speed dependence, the Darwin term), were taken into consideration except of spin-orbital interaction. $S$-, $p$-, and $d$-harmonics were taking into account in the wave function expansion for metal and nonmetal. Brillouin zone integration was held using improved tetrahedron method on the net corresponding to 3375 supporting points.

\section{Results and discussion}

It should be noted that the characteristic feature of apatite compositions, which were obtained with "wet" chemical synthesis, is their nonstoichiometry. The composition of these structures, presumably, can be described by the following formula [18]:

$$
\begin{gathered}
\mathrm{Ca}_{10-\mathrm{x}}\left(\mathrm{HPO}_{4}\right)_{\mathrm{x}}\left(\mathrm{PO}_{4}\right)_{6-\mathrm{x}}(\mathrm{OH})_{2-\mathrm{x}} \cdot n \mathrm{H}_{2} \mathrm{O}, \\
0<x<1, n=0-2.5 .
\end{gathered}
$$

This assumption is mainly based on $\mathrm{Ca}$ shortage in apatite obtained with "wet" chemical synthesis. Total electric charge is compensated by addition of $\mathrm{H}^{+}$ions. It is considered that in addition to $\mathrm{Ca}^{2+}$ ions, $\mathrm{PO}_{4}{ }^{3-}$ and $\mathrm{OH}^{-}$, the ionic groups $\mathrm{H}_{3} \mathrm{O}^{+}$, $\mathrm{H}_{4} \mathrm{O}_{4}{ }^{4-}$ and $\mathrm{HPO}_{4}{ }^{2-}$ are also involved to the "wet" synthesis [18]. In the synthesis process, under partial or total isomorphous substitution of calcium by strontium, $\mathrm{Sr}^{2+}$ ions are isomorphic substituted with $\mathrm{Ca}^{2+}$ ions on the HAP surface by the following scheme [19]:

$$
\begin{aligned}
& \mathrm{Ca}_{10}\left(\mathrm{PO}_{4}\right)_{6}(\mathrm{OH})_{2}+n \cdot \mathrm{Sr}^{2+} \rightarrow \\
\rightarrow & \mathrm{Ca}_{10-n} \mathrm{Sr}_{\mathrm{n}}\left(\mathrm{PO}_{4}\right)_{6}(\mathrm{OH})_{2}+n \cdot \mathrm{Ca}^{2+} .
\end{aligned}
$$

Table contains binding energies of core electrons of metal calcium atoms, calcium and strontium oxides and of the compounds investigated. The binding energy value of Ca $2 p_{3 / 2}$ electrons of calcium atoms in substituted HAP is close to binding energy of the same electrons in $\mathrm{CaCO}_{3}$ that, apparently, is connected with the close degree of ionization of calcium atoms in these compounds.

By transition from $\mathrm{Ca}_{10}\left(\mathrm{PO}_{4}\right)_{6}(\mathrm{OH})_{2}$ to $\mathrm{Ca}_{5} \mathrm{Sr}_{5}\left(\mathrm{PO}_{4}\right)_{6}(\mathrm{OH})_{2}$ the electron binding energy is changed in all atoms (Table). $1 s$ line 
Table. Binding energy of electrons $(\mathrm{eV})$, half-width $(\mathrm{eV})$ of core levels of $\mathrm{Ca}$ and $\mathrm{Sr}$ atoms, their oxides, and also of investigated compounds

\begin{tabular}{|c|c|c|c|c|c|c|c|c|c|}
\hline Compound & $\mathrm{O} 1 s$ & $\mathrm{P} 2 s$ & $\mathrm{P} 2 p$ & Ca $2 p_{3 / 2}$ & Ca $2 p_{1 / 2}$ & Sr $3 s$ & Sr $3 p_{3 / 2}$ & Sr $3 p_{1 / 2}$ & Sr $4 p$ \\
\hline Ca-metal [20] & - & - & - & $\begin{array}{l}344.7 \\
(1.7)\end{array}$ & - & - & - & - & - \\
\hline $\mathrm{CaO}[20]$ & $\begin{array}{c}528.9 \\
(1.4)\end{array}$ & - & - & $\begin{array}{l}346.0 \\
(1.7)\end{array}$ & - & - & - & - & - \\
\hline $\mathrm{Ca}(\mathrm{OH})_{2}[20]$ & 531.2 & - & - & - & - & - & - & - & - \\
\hline $\mathrm{CaCO}_{3}[20]$ & $\begin{array}{l}531.6 \\
(1.6)\end{array}$ & - & - & $\begin{array}{l}347.3 \\
(1.7)\end{array}$ & - & - & - & - & - \\
\hline $\mathrm{Ca}_{10}\left(\mathrm{PO}_{4}\right)_{6}(\mathrm{OH})_{2}$ & $\begin{array}{l}530.4 \\
(2.6)\end{array}$ & $\begin{array}{l}189.6 \\
(3.6)\end{array}$ & $\begin{array}{l}132.0 \\
(2.5)\end{array}$ & $\begin{array}{l}346.2 \\
(2.3)\end{array}$ & 351.2 & - & - & - & - \\
\hline $\mathrm{Ca}_{5} \mathrm{Sr}_{5}\left(\mathrm{PO}_{4}\right)_{6}(\mathrm{OH})_{2}$ & $\begin{array}{c}531.1 \\
(2.1)\end{array}$ & $\begin{array}{l}190.3 \\
(2.9)\end{array}$ & $\begin{array}{l}133.5 \\
(2.8)\end{array}$ & $\begin{array}{l}347.2 \\
(1.9)\end{array}$ & $\begin{array}{l}350.8 \\
(2.7)\end{array}$ & - & $\begin{array}{c}269.0 \\
(3.0)\end{array}$ & $\begin{array}{l}279.3 \\
(4.0)\end{array}$ & - \\
\hline $\mathrm{Sr}_{10}\left(\mathrm{PO}_{4}\right)_{6}(\mathrm{OH})_{2}$ & $\begin{array}{l}531.1 \\
(2.3)\end{array}$ & $\begin{array}{l}190.6 \\
(3.0)\end{array}$ & - & - & - & $\begin{array}{l}357.7 \\
(4.0)\end{array}$ & 269.2 & 279.4 & - \\
\hline Sr-metal [20] & - & - & - & - & - & $\begin{array}{l}356.8 \\
(4.1)\end{array}$ & - & - & 18.2 \\
\hline SrO [20] & $\begin{array}{l}528.2 \\
(1.3)\end{array}$ & - & - & - & - & $\begin{array}{l}357.2 \\
(3.8)\end{array}$ & $\begin{array}{l}268.1 \\
(2.5)\end{array}$ & - & 18.6 \\
\hline $\mathrm{SrCO}_{3}[20]$ & $\begin{array}{c}531.5 \\
(1.5)\end{array}$ & - & - & - & - & $\begin{array}{l}358.0 \\
(4.2)\end{array}$ & $\begin{array}{c}269.0 \\
(2.5)\end{array}$ & - & 19.5 \\
\hline
\end{tabular}

Note: Values of electron binding energy are given relatively to the binding energy of $\mathrm{C} 1 \mathrm{~s}$ electrons $(285.0 \mathrm{eV})$. Measurement inaccuracy is $0.1 \mathrm{eV}$.

of oxygen increases the binding energy by $0.7 \mathrm{eV}$. The lines of calcium core electrons shift towards the larger binding energies, so for $\mathrm{Ca} 2 p_{3 / 2}$ level the shift is $1.0 \mathrm{eV}$, and for the line of $\mathrm{Ca} 2 p_{1 / 2}$ electrons it shifts towards the lower energies - by $0.4 \mathrm{eV}$. In this case $\mathrm{P} 2 s$ line is also shifted towards the higher binding energies by $0.7 \mathrm{eV}$, and $\mathrm{P} 2 p$ line by $1.5 \mathrm{eV}$. Hence, by HAP modification with strontium there are appreciable changes in the electronic structure of the HAP components, and, the larger shift is observed for electron levels located closer to the valent band.

The width of $\mathrm{O} 1 s, \mathrm{P} 2 s, \mathrm{P} 2 p$ and $\mathrm{Ca} 2 p$ lines in the mixed apatite is less, than in the stoichiometric HAP. Thus the significant increase in the binding energy of the corresponding lines is observed indicating electronic density loss of calcium, oxygen and phosphorus atoms. Hence, metal sublattice in mixed HAP, is more "loosened". Most likely, indirect interaction between atoms of metal weakens that affects the core lines width. It also indicates increase of the covalent component in the general balance of chemical bond.

In strontium hydroxyapatite there is no shift of $\mathrm{O} 1 \mathrm{~s}$ line, $\mathrm{P} 2 \mathrm{~s}$ line shifts towards the higher binding energies by $0.3 \mathrm{eV}$. Sr $3 p_{3 / 2}$ line shifts by $0.2 \mathrm{eV}$, and $\mathrm{Sr} 3 p_{1 / 2}$ line shifts by $0.1 \mathrm{eV}$ towards the higher binding energies. The binding energy of $\mathrm{Sr} 3 p_{3 / 2}$ and $\mathrm{Sr} 3 s$ electrons of strontium atoms in substituted HAP and Sr-HAP is close to the binding energy of the same electrons in $\mathrm{SrCO}_{3}$ that, apparently, is connected with the close degree of ionization of strontium atoms in these compounds.

Our research for replacement of calcium for uranium [21] showed the same pattern of position changes in the core levels of electrons for all elements of compound. This indicates that increase of proportion of the covalent component in chemical bond due to substitution of calcium for strontium is little dependent on the ionic charge, and, apparently, related to geometrical size of the ion, and, consequently, to small changes of the lattice parameters.

The obtained results are in a good agreement with X-ray spectral investigation of the oxygen state (Fig. 1,2). The obtained $O$ $\mathrm{K} \alpha$-spectra in apatites (Fig. 1) are notable for almost full coincidence of shape of the spectra, confirming the lability of apatite structure in the isomorphic substitution. There is observed a shift of their centres of gravity which is within the experimental error (Fig. 2), indicating the electron density redistribution while preserving the nature of the chemical bond. It should be 




Fig. 1. $\mathrm{OK}_{\alpha}$-spectra of investigated compounds.

noted that significant changes in the gravity centre for $\mathrm{Ca}_{5} \mathrm{Sr}_{5}\left(\mathrm{PO}_{4}\right)_{6}(\mathrm{OH})_{2}$ are apparently due to the influence of different geometric size of calcium and strontium ions, and, consequently, loosening of the indirect interaction between the atoms of metal.

Calcium substitution for strontium in calcium hydroxyapatite significantly changes the shape of full density of states of the crystal (Fig. 3). There is the peaks splitting as in the bottom and at the top of the valent band, which is possible, as has already been shown to be associated with reduced symmetry tetrahedra due to increasing size of the metal atoms.

The $B$ feature corresponding to the main maximum in DOS curve is generated basically by valent states of oxygen and strontium, without participation of valent states of phosphorus, as evident in the calculation data (Fig. 3). The $D$ feature is generated by that part of $2 p$ electron density of oxygen which takes part in a chemical bond with phosphorus and reflects, basically, phosphorus $p$-states.

Low-intensity $A$ feature in the DOS curve reflects the bond between hydroxyl ion metal atoms. The feature in the DOS curve near $2.5 \mathrm{eV}$ is observed only for $\mathrm{O}_{(4)} s, \mathrm{O}_{(4)}$ $p$ and $\mathrm{H} s$ partial densities of electronic states. The absence of appreciable features in the curves of the partial densities of metal in this energy range may indicate

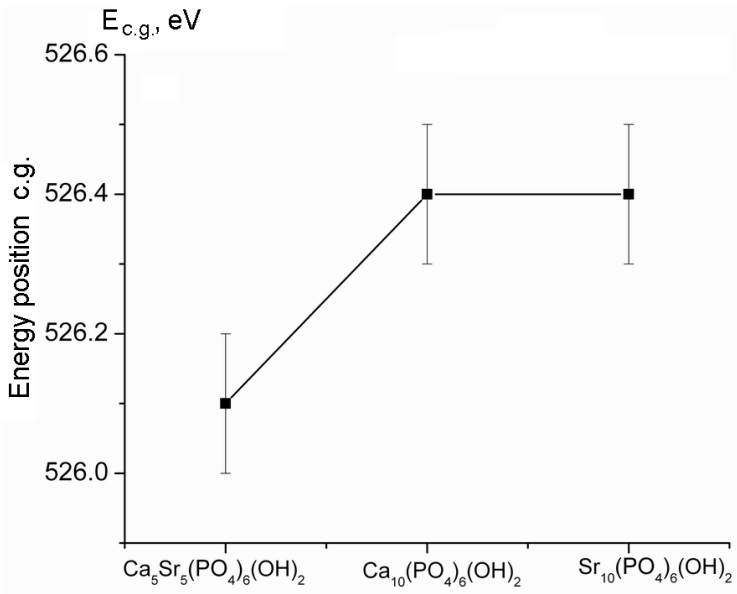

Fig. 2. Energy position of centers of gravity of $\mathrm{OK}_{\alpha}$-spectra of investigated compounds.

that the indirect metal-metal interaction in Sr-HAP is virtually absent.

The presence of such interaction in calcium hydroxyapatite, probably, is determined with the emerging $d$-cover having characteristic dependence of effective potential on distance. Based on analysis of characteristics of the X-ray spectra and calculation data of calcium and strontium hydroxyapatite it is possible to conclude that in Sr-HAP the partial contribution of $\mathrm{H} \mathrm{s}$-states into the DOS considerably increases. Thus the main maximum of $\mathrm{H} s$-density in the HAP is near $15 \mathrm{eV}$, whereas in the Sr HAP it is near $22 \mathrm{eV}$. The band splitting near $15 \mathrm{eV}$ in the HAP may indicate the complex mechanism of hybridization of hydrogen $s$ density with $\mathrm{Ca}_{(2)} p$ and $\mathrm{Ca}_{(2)} d$ densities through $\mathrm{O}_{(4)} p$ states. There is one Sr-HAP $\mathrm{H} s$-density peak in this range with intensity lower than of the Ca-HAP. The feature near $2.5 \mathrm{eV}$ in $\mathrm{H}$ s-density curve of the $\mathrm{Sr}$ HAP has more complex structure consisting of two peaks generated as it was mentioned above, by the electronic densities of hydroxyl atoms of $\mathrm{O}_{(4)}(s, p)$-states.

Most likely, the high core electron density of strontium atoms in the free state in comparison with calcium atoms leads to the fact that strontium $d$-cover nucleation in the crystal is accompanied with its higher binding energy, than for calcium (for the metal strontium binding energy of $d$-electrons is near $15 \mathrm{eV}$ whereas for calcium it is near $5 \mathrm{eV}$ ) and, hence, indirect metalmetal interaction for strontium apatite in triangles of metal atoms is less expressed. 

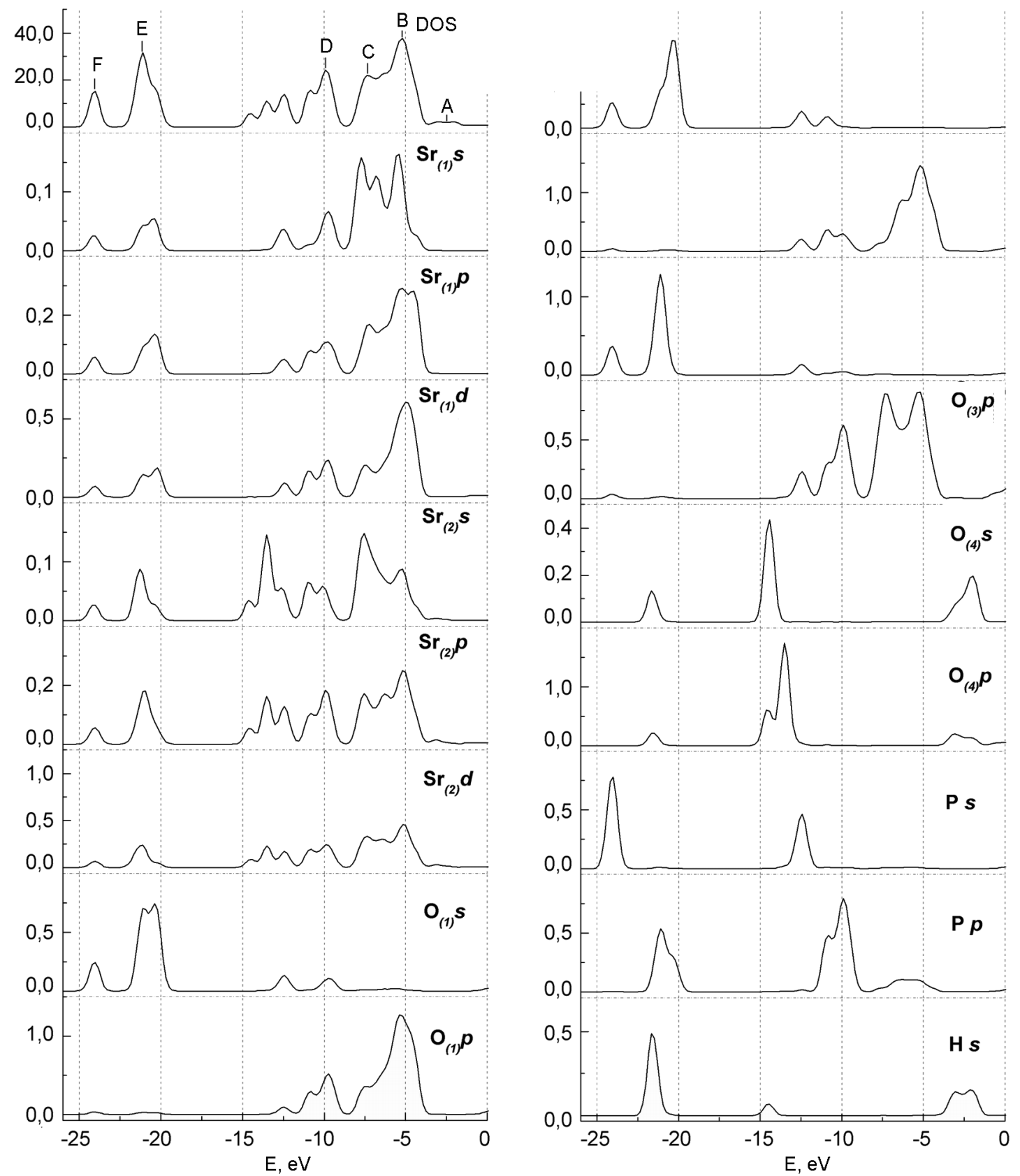

Fig. 3. Full and partial densities of $\mathrm{Sr}_{10}\left(\mathrm{PO}_{4}\right)_{6}(\mathrm{OH})_{2}$ states.

\section{Conclusions}

Metal sublattice in mixed HAP is more "loosened". Significant increase in binding energy of core levels is observed for calcium, oxygen and phosphorus atoms, indicating electronic density loss from these atoms. Most likely, indirect interaction between atoms of the metal weakens that affects the width of the core lines. It also indicates the increase of the covalent component in general balance of chemical bond.
Increase of proportion of the covalent component in the chemical bond due to substitution calcium for strontium is little dependent on the ionic charge, and, apparently, related to geometrical size of the ion, and, consequently, to small changes of the lattice parameters.

High core electron density of strontium atoms in the free state in comparison with calcium atoms leads to the fact that strontium $d$-cover nucleation in the crystal is accompanied with its higher binding energy, 
than for calcium (for metal strontium binding energy of $d$-electrons is near $15 \mathrm{eV}$ whereas for calcium it is near $5 \mathrm{eV}$ ) and, hence, indirect metal-metal interaction for strontium apatite in triangles of the metal atoms is less expressed.

\section{References}

1. C.C. Fuller, J.R.Bargar, J.A.Davis et al., Environ. Sci.Technol., 36, 158 (2002).

2. E.V.Shutkova, Yu.I.Tarasevich, Khimiya $i$ Tehnologiya Wody, 26, 556 (2004).

3. F.Fernane, M.O.Mecherri, P.Sharrock et al., Mater. Characterization, 59, 554 (2008).

4. F.Z.Boujrhal, E.K.Hlil, R.Cherkaoui, Rad. Phys. and Chem., 69, 1 (2004).

5. D.J.Cherniak, Chem. Geology, 219, 297 (2005).

6. J.Gomez del Rio, P.Sanchez, P.J.Morando et al., J.Chermosphere, 64, 1015 (2006).

7. D.Marchat, D.Bernache-Assollant, E.Champion, J.Hazardouz Mater., 139, 453 (2007).

8. J.Peng, Y.Song, P.Yuan et al., J.Hazardous Materials, 161, 133 (2009).

9. R.Zhu, R.Yu, J.Yao et al., Catalysis Today, 139, 94 (2008).

10. A.A.Kluchnikov, E.M.Pazuhin, Radioaktivnie Othody AES i Metody Obrajenia s Nimi, Energoatomizdat, Moscow (2005) [in Russian].
11. M.S.Phillipova, T.N.Perelet, Visnik NTUU "KPI", seria "Girnitstvo", 18, 105 (2009).

12. I.A.Sobolev, I.P.Korenkov, L.M.Khomchik et al., Ohrana Okrujayuschey Sredy pri Obezvrejivanii Radioaktivnih Othodov, Energoatomizdat, Moscow (1989) [in Russian].

13. I.W.Donald, B.L.Metcalfe, R.N.J.Taylor, J. Mater. Science, 32, 5851 (1997).

14. S.Dimovic, I.Smiciklas, M.Sljivic-Ivanovic et al., J.Soils Sediments, 13, 383 (2013).

15. V.L.Karbivskyy, N.A.Kurgan, A.S.Litovchenko et al., J.Mater. Sci. and Engin., 3, 52 (2009).

16. K.Popa, J.Radioanal Nucl Chem., 298, 1527 (2013).

17. V.R.Vermeul, J.E.Szecsody, B.G.Fritz et al., J.Groundwater Monitoring \& Remediation, 34, 28 (2014).

18. T.Kanazawa, Neorganicheskie Phospatnie Materiali, Naukova Dumka, Kiev (1998).

19. A.P.Shpak, V.L.Karbovskii, V.V.Tratchevskii, Apatites, Academperiodika, Kiev (2002).

20. N.Ikeo, Y.Iijima, N.Niimura et al., Handbook of X-ray Photoelectron Spectroscopy, JEOL Ltd, Tokyo (1991).

21. V.L.Karbivskyy, A.G.Vahney, R.V.Didenko et al., Metalofizika i Noveyshie Teknologyy, 25, 1431 (2003). 